\title{
Duct- to islet-cell differentiation and islet growth in the pancreas of duct-ligated adult rats
}

\author{
R.N. Wang, G. Klöppel, L. Bouwens \\ Department of Experimental Pathology, Free University of Brussels, Campus Jette, Brussels, Belgium
}

\begin{abstract}
Summary We investigated the growth of islet beta and alpha cells in adult rats which had undergone partial pancreatic duct ligation. Whereas the non-ligated head portion of the pancreas remained unaffected in terms of histology and cell population dynamics, the ligated tail part of the pancreas showed pronounced changes in histology and cell growth. These changes included replacement of exocrine acini by ductal complexes and significant growth of islet cells. Using immunocytochemistry and morphometry, we found that the beta-cell population had nearly doubled within 1 week and that a smaller, but also significant growth of the alpha-cell population had occurred. In addition, small islets and islet-cell clusters were more numerous in the pancreatic tail, indicating islet neogenesis. The bromodeoxyuridine (BrdU) pulse labelling index of beta and alpha cells increased five fold and threefold, respectively, in the tail. However, the observed beta-cell labelling index remained below $1 \%$ which was largely insufficient to explain the increased number of beta cells. This indicates that recruitment from a proliferating stem-
\end{abstract}

cell compartment was the main source for the betacell hyperplasia. A tenfold-elevated BrdU labelling index $(18 \%)$ was observed in the duct-cell compartment which was identified by specific immunostaining for cytokeratin 20. Transitional cytodifferentiation forms between duct cells expressing cytokeratin 20 and beta cells expressing insulin, or alpha cells expressing glucagon, were demonstrated by double immunostaining. Pancreatic duct ligation also induced the expression of the beta-cell-specific glucose transporter type 2 (GLUT-2) in duct cells, indicating their metaplastic state. We concluded that in this adult rat model, the proliferation and differentiation of exocrine duct cells represents the major mechanism of endocrine beta-cell neogenesis. Our study thus demonstrates that in normal adult rats islet-cell neogenesis can be reactivated by stimulation of pancreatic duct cells. [Diabetologia (1995) 38: 1405-1411]

Key words Pancreatic duct ligation, duct-cell differentiation, beta-cell neogenesis, immunocytochemistry, morphometry.
Understanding the population dynamics of islet beta cells is important for understanding the pathogenesis of diabetes and for disease intervention [1-4]. Beta cells have a limited capacity for proliferation $[2,5]$,

Received: 11 April 1995 and in revised form: 19 June 1995

Corresponding author: Professor Dr. L. Bouwens, Department of Experimental Pathology, Free University of Brussels, Campus Jette, Laarbeeklaan 103, B-1090 Brussels, Belgium Abbreviations: BrdU, Bromodeoxyuridine; CK20, cytokeratin 20; GLUT-2, glucose transporter type 2; LI, labelling index; $\mathrm{CBR}$, cell birth rate. but their population has been shown to expand considerably due to the differentiation of ductal stem cells in the fetus [6-10] and neonate [11-13]. Duct cells retain the capacity for endocrine differentiation after the perinatal period; islet neoformation from ducts has been observed under certain experimental conditions such as $90 \%$ pancreatectomy in young rats $[14,15]$, transgenic mice over-expressing certain growth factors or cytokines [16-18], and cellophane wrapping of the pancreas in adult hamsters $[19,20]$. Furthermore, co-transplantation of adult rodent ductal epithelium with fetal mesenchyme led to the appearance of endocrine islets in the recipient [21]. 
Ligation of the ductal tree of the pancreatic tail in adult rats offers the possibility of studying the growth dynamics of pancreatic duct and endocrine cells [22]. Using this model, we tested the hypothesis of islet neoformation from duct cells in adult animals by applying (a) stereological morphometry to measure growth, (b) bromodeoxyuridine (BrdU) pulse labelling to quantitate the generation of new cells, and (c) immunocytochemical markers to demonstrate ductand islet-cell differentiation.

\section{Materials and methods}

Animals. Male Wistar rats (Katholieke Universiteit Leuven, Proefdierencentrum, Heverlee, Belgium) weighing 280-300 g and 3 months of age were used. All animals were maintained under standard conditions and were fed rodent chow and water ad libitum.

Surgical procedure. Duct-ligated animals were anaesthetized with diethyl ether, and a laparotomy was performed through a midline abdominal incision. The pancreatic ducts of the gastric and splenic segments were ligated, according to the method of Hultquist and Jönsson [22]. The ligation was carefully made from the point where the pancreas is attached to the first portion of the duodenum to the point just before its attachment to the transverse colon. The ligated tail portion accounts for $50-60 \%$ of the entire pancreas. Normal (untreated) animals, not subjected to any surgical procedure, were used as controls.

Sampling and tissue preparation. Duct-ligated animals were killed 1,2, 3, 5, 7 and 14 days after the operation. Six to eight rats were studied on days 3,7 and 14 , and two to three rats on days 1,2 and 5. Six untreated animals were killed at the onset of the experiments. One hour prior to death, animals were injected intraperitoneally with BrdU (Sigma, St.Louis, Mo, USA) at a dose of $50 \mathrm{mg} / \mathrm{kg}$ body weight. Pancreatic head and tail portions were dissected at the site of the duct ligature in the treated rats and at the corresponding site of the pancreas in the untreated animals. These specimens were processed separately for weight and volume determination, prior to fixation and embedding in paraffin $[12,13]$. Three additional rats per time point were killed for determination of total insulin content in the pancreatic tail and head. Blood samples were obtained for measuring glucose (Glucoscot II device; Kyoto Daiichi Kagaku, Kyoto, Japan) and serum insulin levels [23].

Double immunocytochemistry. Two series of ten 3-um-thick paraffin sections per tissue block were prepared at an approximately equidistant level. Consecutive sections were double immunostained for $\mathrm{BrdU}$ and pancreatic hormone (insulin or glucagon), using the $\mathrm{ABC}$ technique as described previously [12, 13]. BrdU was detected by a mouse monoclonal anti-BrdU antibody (Euro-Diagnostics, Apeldoorn, The Netherlands) diluted 1:10. Beta cells were stained with a mouse monoclonal anti-human insulin antibody diluted 1:50 (Biogenex, San Ramon, Calif., USA), and alpha cells were stained with a mouse monoclonal anti-human glucagon antibody diluted 1:1000 (Novo Nordisk, Gentofte, Denmark) after overnight incubation at $4^{\circ} \mathrm{C}$. 'To identify duct cells cytokeratin 20 (CK20) was detected by a mouse monoclonal anti-human CK20 (clone Ks 20.8; Dako, Glostrup, Denmark) at a dilution of 1:25 [13]. Antibody to rabbit polyclonal anti-glucose transporter type 2
(GLUT 2, 1:4000 dilution, East Acres Biologicals, Southbridge, Mass., USA), a beta-cell marker, was also used. Staining was visualized by incubation either in 3,3'-diaminobenzidinetetrahydro-chloride or naphtol-AS-MX-phosphate/fast red TR salt (Sigma) as chromogens. Controls consisted of omission of the primary antibody of the first or of the second cycle reaction. The specificity of the antibody against glucose transporter type 2 (GLUT-2) was determined by absorption with excess rat GLUT-2 peptide (kindly provided by Dr. A. Jörns, University of Hannover, Germany) overnight at $4{ }^{\circ} \mathrm{C}$.

Morphometry. Computer-assisted measurement of total alphaand beta-cell areas in sections from the pancreatic head and tail was done at different time points according to previously described methods [12]. The total volume of the alpha- and beta-cells was calculated by the stereologic morphometric method with the following formula: $A / A p=V / V p$ ( $A$, hormone-immunoreactive area; Ap, pancreatic tissue area; $V$, total endocrine cell volume; $V_{p}$, volume of pancreas) $[12,24$ 26]. The individual beta-cell profile area was measured in 12 randomly selected islets by dividing the insulin-immunoreactive islet area by the number of insulin-positive cells. In addition the individual cell area was measured for at least 20 single beta cells (located outside islets).

To calculate the BrdU labelling index (BrdU LI), the number of cells which were positive for both insulin and BrdU or glucagon and BrdU was determined and expressed as a mean percentage of beta or alpha cells, respectively, positive for BrdU. Also, the BrdU LI of duct cells was counted by double immunostaining for BrdU and CK20. For each animal at least 500 cells were counted per pancreatic head and tail. Based upon the measured BrdU LI and the estimated S-phase duration (Ts) of beta cells $(6.4 \mathrm{~h})$ previously described $[9,12,13]$, the cell birth rate (CBR; i.e., the production of new cells per day) can be calculated with the equation: $\mathrm{CBR}=\left(\mathrm{LI} \mathrm{Ts}{ }^{-1}\right.$. $24 \mathrm{~h}$. This data is expressed as cells $\cdot$ cell $^{-1} \cdot$ day $^{-1}$. The potential doubling time of the population can be calculated by the equation: $\mathrm{t}_{\mathrm{PD}}=1 / \mathrm{CBR}[27]$.

\section{Statistical analysis}

Values are expressed as mean \pm SEM. A two-tailed paired or unpaired Student's $t$-test was used to test significance of the results.

\section{Results}

Physiologic and metabolic data. General physiologic and metabolic data are given in Table 1 . The body weight of the duct-ligated animals did not increase over the 14-day study period and the animals lost weight in the initial 3 days $(p<0.01)$. The weight of the pancreatic head portion did not change significantly, but that of the tail portion decreased considerably. Blood glucose levels decreased significantly throughout the study period, whereas plasma insulin levels and total pancreatic insulin content remained unchanged.

Formation of ductal complexes and small islets. The histological appearance of the pancreatic tail pro- 
Table 1. Body weight, blood glucose level, pancreatic weight and pancreatic insulin content in untreated and duct-ligated rats at different time points

\begin{tabular}{|c|c|c|c|c|c|c|}
\hline \multirow{2}{*}{$\begin{array}{l}\text { Experimental } \\
\text { group }\end{array}$} & \multirow{2}{*}{$\begin{array}{l}\text { Body weight } \\
\text { (g) }\end{array}$} & \multirow{2}{*}{$\begin{array}{l}\text { Blood glucose } \\
(\mathrm{mmol} / \mathrm{l})\end{array}$} & \multicolumn{2}{|c|}{ Pancreatic weight (mg) } & \multirow{2}{*}{$\begin{array}{l}\text { Plasma insulin } \\
\text { (ng/ml) }\end{array}$} & \multirow{2}{*}{$\begin{array}{l}\text { Pancreatic } \\
\text { insulin } \\
\text { ( } \mu \mathrm{g} / \text { pancreas) }\end{array}$} \\
\hline & & & head & tail & & \\
\hline Untreated & $308 \pm 7.0(9)$ & $6.2 \pm 0.3$ & $385 \pm 25.2$ & $576 \pm 32.8$ & $3.4 \pm 0.5$ & $150 \pm 6.7(3)$ \\
\hline PDL-day 7 & $306 \pm 10.0(9)$ & $4.7 \pm 0.2^{\mathrm{a}}$ & $399 \pm 20.8$ & $276 \pm 11.1^{\mathrm{a}}$ & $5.2 \pm 1.1(3)$ & $150 \pm 11.6(3)$ \\
\hline PDL-day 14 & $307 \pm 8.7(8)$ & $4.6 \pm 0.2^{\mathrm{a}}$ & $444 \pm 37.3$ & $188 \pm 29.4^{\mathrm{a}}$ & $4.4 \pm 0.2(3)$ & $166 \pm 17.5(3)$ \\
\hline
\end{tabular}

Values are means $\pm \mathrm{SEM}$, with numbers of animals in parentheses. ${ }^{\mathrm{a}} p<0.001 ;{ }^{\mathrm{b}} p<0.01$ compared to untreated animals. PDL, Pancreatic duct-ligated rats

foundly changed after duct ligation, whereas the parenchyma of the non-ligated head portion of the pancreas did not differ from that of untreated rats. During the first 3 days after ligation normal acinar cells disappeared and were replaced by small ductal structures which formed ductal complexes. These changes, which have already been described previously in detail by others $[28,29]$, were associated with a fibrotic and inflammatory reaction involving numerous macrophages. On the fifth day, the pancreatic tail consisted of islets and ductal complexes which were embedded in connective tissue (Fig. 1A). Many cells of the connective tissue and ductal epithelium incorporated BrdU (Fig. 1B). After day 5, there was an increase in small islets, islet-cell clusters and single islet cells (recognized by hormone staining) (Fig.2). BrdU labelling was found in islet cells, but to a much lower extent than in duct cells (see below).

Appearance of transitional and metaplastic cells. All duct cells stained for CK20 (Fig.1A). In addition, duct-associated cells expressing both CK20 and insulin or glucagon were detected (Fig. 3). These transitional cells were most frequent on days 3 and 5 postligation and later disappeared. In the non-ligated head portion, or in the pancreas of untreated rats, such transitional cells co-expressing islet hormone and CK20 were not observed.

Immunostaining for GLUT-2, a known beta-cell marker, gave a weak reaction over ducts from the ligated portion, but not over ducts from the non-ligated portion of the pancreas (Fig.4). In untreated rats GLUT-2 immunoreactivity was only seen on beta cells. Whereas GLUT-2 staining in islets was membrane-associated, it was largely cytoplasmic in the duct cells. The GLUT-2 reactivity in islets and ducts could be blocked by pre-incubating the antiserum with the GLUT-2 peptide.

Morphometry. The volume of the alpha- and beta-cell population was determined by morphometry in the head and tail of the pancreas (Fig. 5). During the first week after ligation there was nearly a doubling (1.7fold) of the beta-cell population in the pancreatic tail. No difference in the population size was found in the

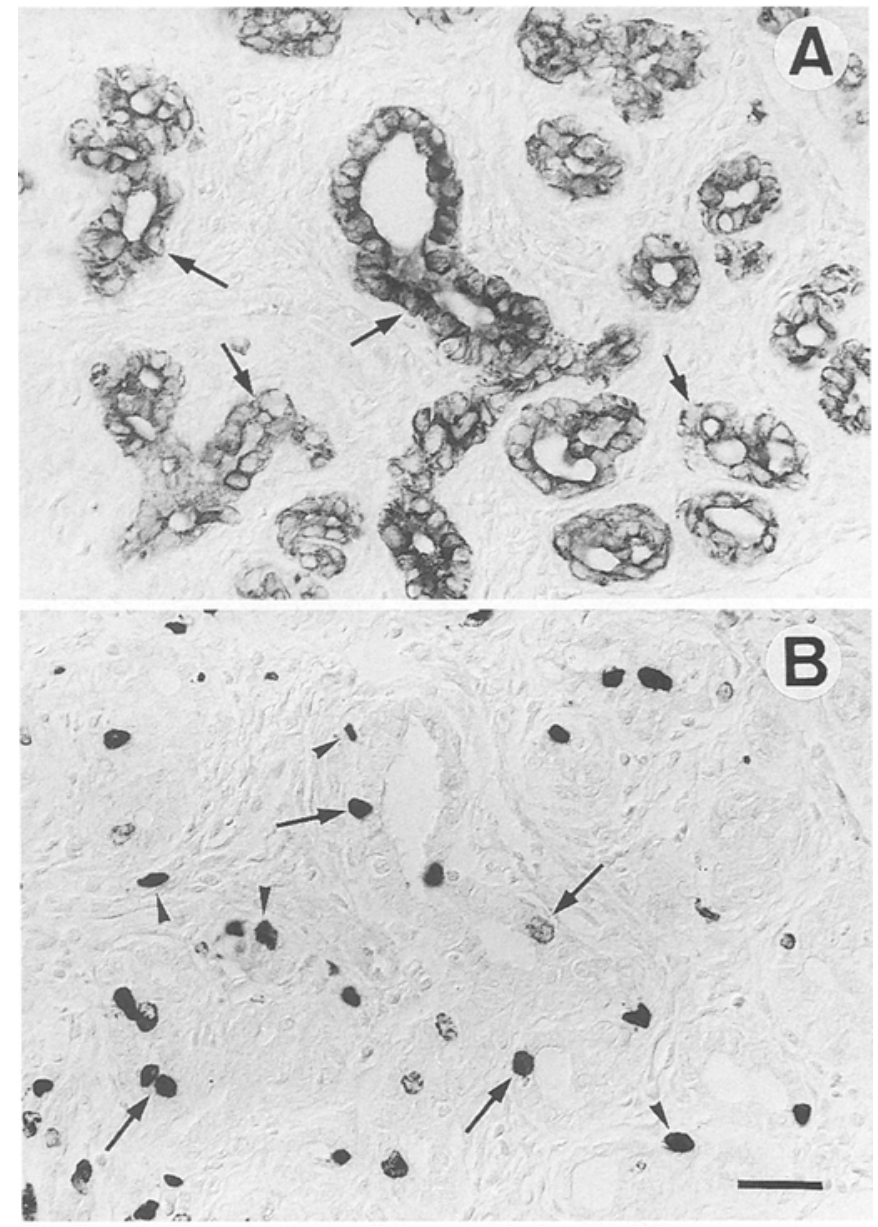

Fig. 1 (A-B). Consecutive sections from the pancreatic tail, 5 days post-ligation. Immunostaining for CK20 (A) only labels the duct cells (arrows). BrdU signals (B) are found in numerous duct cell nuclei (arrows) as well as in interstitial tissue cells (arrowheads). Bar, $30 \mu \mathrm{m}$

non-ligated portion (head) of the pancreas. There was also a significant increase of the alpha-cell volume but this was only $20-30 \%$ above the normal level. The individual size (area) of islet beta-cell profiles remained stable over the experimental period (Table 2).

When an empirical distinction was made between small islets (and islet-cell clusters) with a profile area of less than $1000 \mathrm{\mu m}^{2}$, and larger islets, we found a sig- 


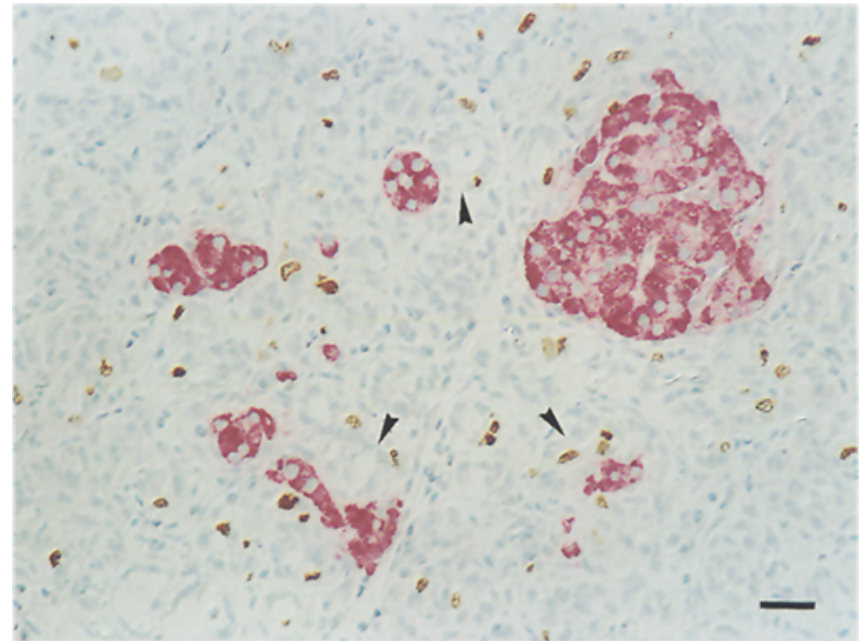

Fig. 2. Section from the pancreatic tail, 7 days post-ligation. Double immunostaining for BrdU (brown) and insulin (red). Small islets, islet-cell clusters and single islet cells are common at this time point. Arrowheads: duct. Bar, $30 \mu \mathrm{m}$

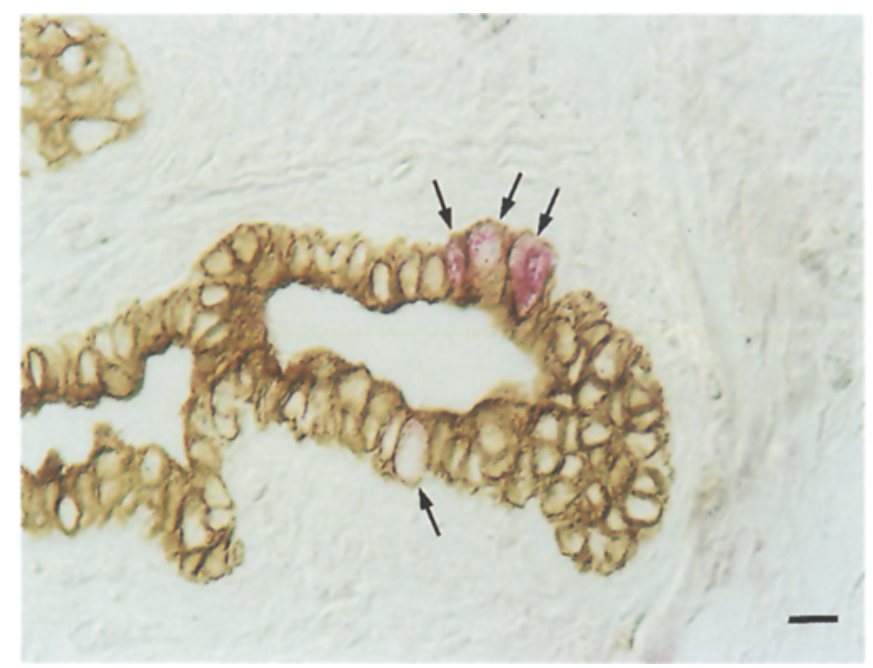

Fig. 3. Section from the pancreatic tail, 5 days post-ligation. Double immunostaining for CK20 (brown) and insulin (red). Duct cells are seen which express both insulin and CK20 (arrows). Bar, $10 \mu \mathrm{m}$

nificant difference in the tail portion of the pancreas between untreated and duct-ligated animals on day 7 (Table 3). In the tail of the ligated rats, there were significantly more small islets and islet-cell clusters $\left(<1000 \mu \mathrm{m}^{2}\right)$, i.e. $67 \mathrm{vs} 54 \%$ in the untreated rats. The number of single beta cells was also significantly increased in the tail of the ligated rats on day 7 $(p<0.001)$. In addition, these single beta cells were smaller in individual size (Table 2).

BrdU labelling index. The BrdU pulse LI of beta, alpha and duct cells was increased by a factor of 5,3 and 10, respectively, in the pancreatic tail of the ligated rats (Fig.6) as compared to untreated rats. How-
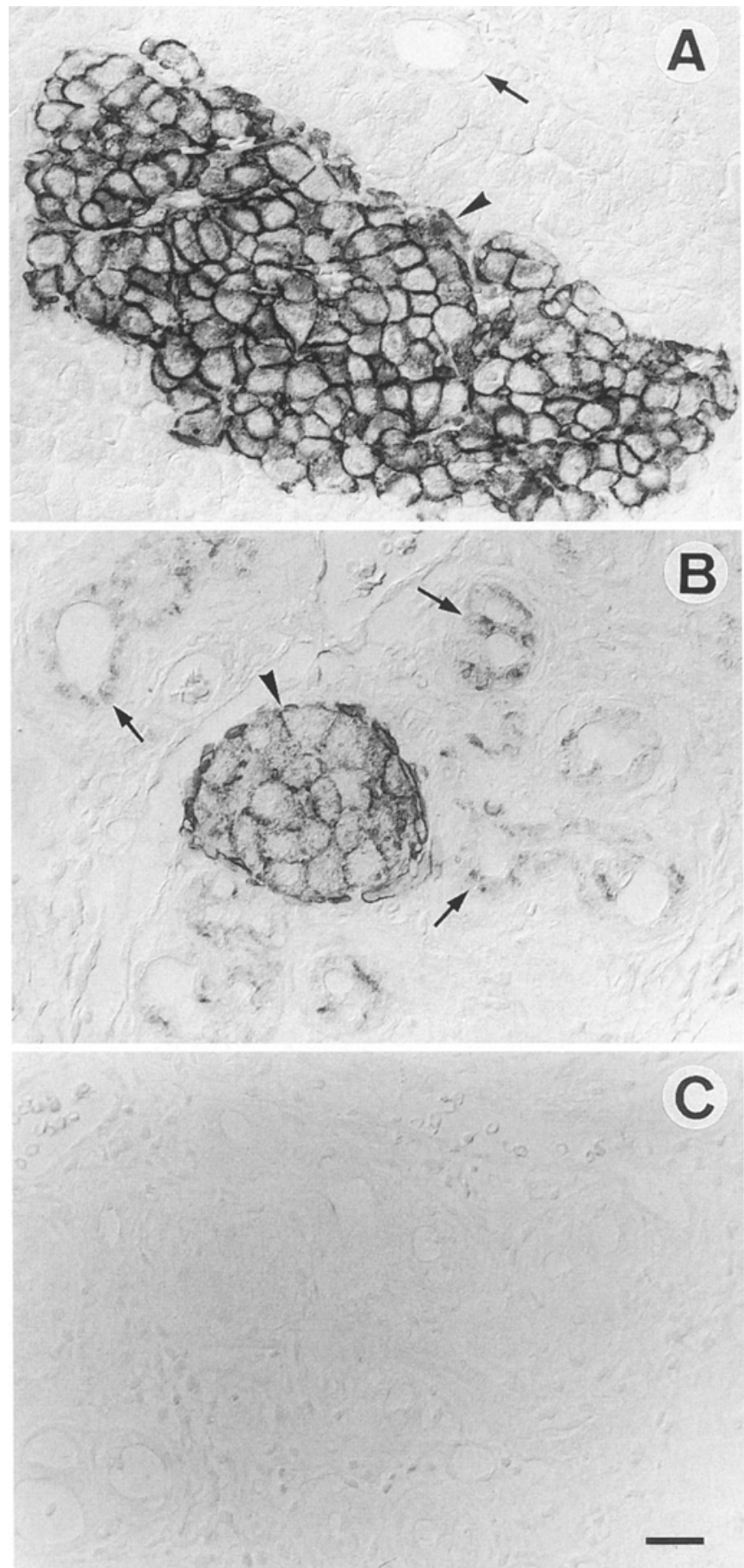

Fig. 4 (A-C). Section from an untreated rat (A) and from the pancreatic tail of a duct-ligated rat 7 days post-ligation $(\mathbf{B}, \mathbf{C})$. Immunostaining for GLUT-2 is present on the membrane of islet beta cells $(\mathbf{A}, \mathbf{B})$ and the ductal cells $(\mathbf{B})$. The immunoreactivity was completely abolished when the antiserum was preincubated with excess GLUT-2 peptide (C). Arrows, duct cells; arrowheads, islet cells. Bar, $20 \mu \mathrm{m}$

ever, the LI of the islet cells remained well below $1 \%$, whereas the duct-cell proliferation was impressive (Fig. 1B) with up to $18 \%$ of the cells being labelled. It was noted that the proliferative peak for duct cells and alpha cells occurred earlier (day 3), than 

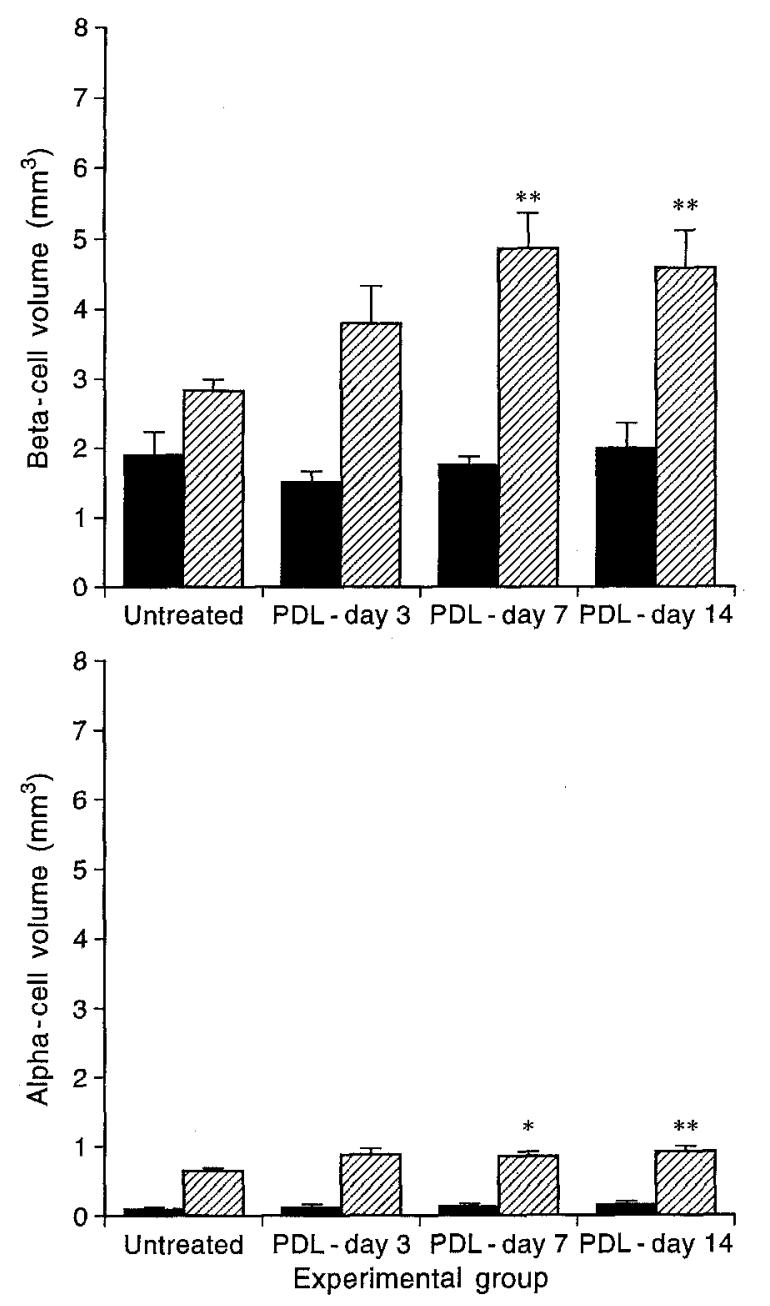

Fig.5. Total beta- and alpha-cell volumes in untreated and duct-ligated rats at different time points. Statistical analysis showed significant increase in the ligated tail of the pancreas on day 7 and 14 compared to the earlier time points and untreated animals, and no significant differences in the non-ligated head of the pancreas. $* p<0.05,{ }^{* *} p<0.01$. PDL, Pancreatic duct ligation;, head portion, tail portion

for beta cells (day 7). In the non-ligated head portion of the pancreas, there was no increase in proliferative activity (Fig.6). During the first post-ligation week, BrdU labelled cells were also frequent in the interstitial tissue (Fig. 1B).

\section{Discussion}

Our objective was to investigate duct ligation of the pancreas as a model of islet beta-cell growth in adult rats. In particular, we wanted to know whether betacell growth results from replication of differentiated beta cells or from differentiation of non-endocrine precursors. In previous studies in which duct-ligated rats were followed up to a year post-operatively, a regenerative activity of the endocrine cells in the ligated part of the pancreas was observed [30-32]. These studies suggested that new islets may form from duc-
Table 2. Cellular profile area of individual beta cells located in islets or as single cells, in untreated and duct-ligated rats at different time points

\begin{tabular}{llllll}
\hline $\begin{array}{l}\text { Experimental } \\
\text { group }\end{array}$ & \multicolumn{2}{l}{ Pancreatic head $\left(\mu \mathrm{m}^{2}\right)$} & & \multicolumn{2}{l}{ Pancreatic tail $\left(\mu \mathrm{m}^{2}\right)$} \\
\cline { 2 - 3 } \cline { 5 - 6 } & Islet & Single & & Islet & Single \\
\hline Untreated & $134 \pm 1.0$ & $122 \pm 2.7$ & & $135 \pm 1.2$ & $125 \pm 2.8^{\mathrm{n}}$ \\
PDL-day 3 & $127 \pm 1.8^{\mathrm{b}}$ & $112 \pm 4.2$ & & $128 \pm 1.3^{\mathrm{c}}$ & $114 \pm 2.1^{\mathrm{b}}$ \\
PDL-day 7 & $133 \pm 1.9$ & $116 \pm 2.1$ & & $132 \pm 1.4$ & $109 \pm 2.5^{\mathrm{c}}$ \\
PDL-day 14 & $128 \pm 2.8^{\mathrm{a}}$ & $114 \pm 3.3$ & & $126 \pm 1.5^{\mathrm{c}}$ & $112 \pm 2.3^{\mathrm{b}}$ \\
\hline
\end{tabular}

Values are mean \pm SEM. ${ }^{\mathrm{a}} p<0.05 ;{ }^{\mathrm{b}} p<0.01 ;{ }^{\mathrm{c}} p<0.001 \mathrm{com}-$ pared to untreated animals. Statistical analysis showed significant differences between the islet and single beta cells in each group. PDL, Pancreatic duct-ligated rats

Table 3. Proportion of beta-cell clusters $<1000 \mu \mathrm{m}^{2}$, and of single beta cells, over the total beta-cell area in untreated and duct-ligated rats at different time points

\begin{tabular}{|c|c|c|c|c|}
\hline \multirow[t]{2}{*}{$\begin{array}{l}\text { Experimental } \\
\text { group }\end{array}$} & \multicolumn{2}{|c|}{$\begin{array}{l}\text { Beta-cell area } \\
\left(<1000 \mu \mathrm{m}^{2}\right)(\%)\end{array}$} & \multicolumn{2}{|c|}{ Single beta cells (\%) } \\
\hline & Head & Tail & Head & Tail \\
\hline & & & & \\
\hline PDL-day 3 & & & & \\
\hline PDL-day 7 & $8 \pm 1.6$ & $66.6 \pm$ & $0.93=$ & $2.14 \pm 0.1^{b}$ \\
\hline PDL-day 14 & $52.3 \pm 1.6$ & $56.3 \pm 3.0$ & $0.94 \pm 0.2$ & $1.86 \pm 0.3^{\mathrm{c}}$ \\
\hline
\end{tabular}

Values are mean percentage \pm SEM. ${ }^{a} p<0.01$ compared to untreated rats and other time points of duct-ligated groups. ${ }^{\mathrm{b}} p<0.001 ;{ }^{c} p<0.01$ compared to untreated rats. PDL, Pancreatic duct-ligated rats

tal precursor cells, but the relative contribution of this mechanism and of islet-cell replication could not be determined. In addition, no direct evidence for a transition from duct to islet cells was provided.

Using computer-assisted stereological morphometry, we demonstrated a significant increase in betacell volume in the duct-ligated part of the pancreas, whereas there was no increase in the non-ligated part of the pancreas. The beta-cell volume in the ligated part nearly doubled (1.7-fold) within 7 days. This was entirely due to hyperplasia, thus increased cell number, since the individual beta-cell size did not increase over the study period. The observed increase in small islets, islet-cell clusters and scattered single islet cells suggested islet neogenesis. Although betacell hyperplasia was accompanied by a significantly increased BrdU pulse LI (5 times that of controls), this proliferative activity of differentiated beta cells could not account for the observed increase in total beta-cell volume. Based on an average pulse LI of $0.5 \%$ between day 3 and day 7, a potential CBR of $1.9 \%$ per day (or 0.019 cells $\cdot$ cell $^{-1} \cdot$ day $^{-1}$ ) or a potential population doubling time $\left(\mathrm{t}_{\mathrm{PD}}\right)$ of 53 days can be calculated (see Materials and methods). The time period of 53 days, however, is much longer than the population doubling in 1 week which we observed. We must therefore conclude that the replication of differentiated, i.e. insulin-expressing, beta cells 

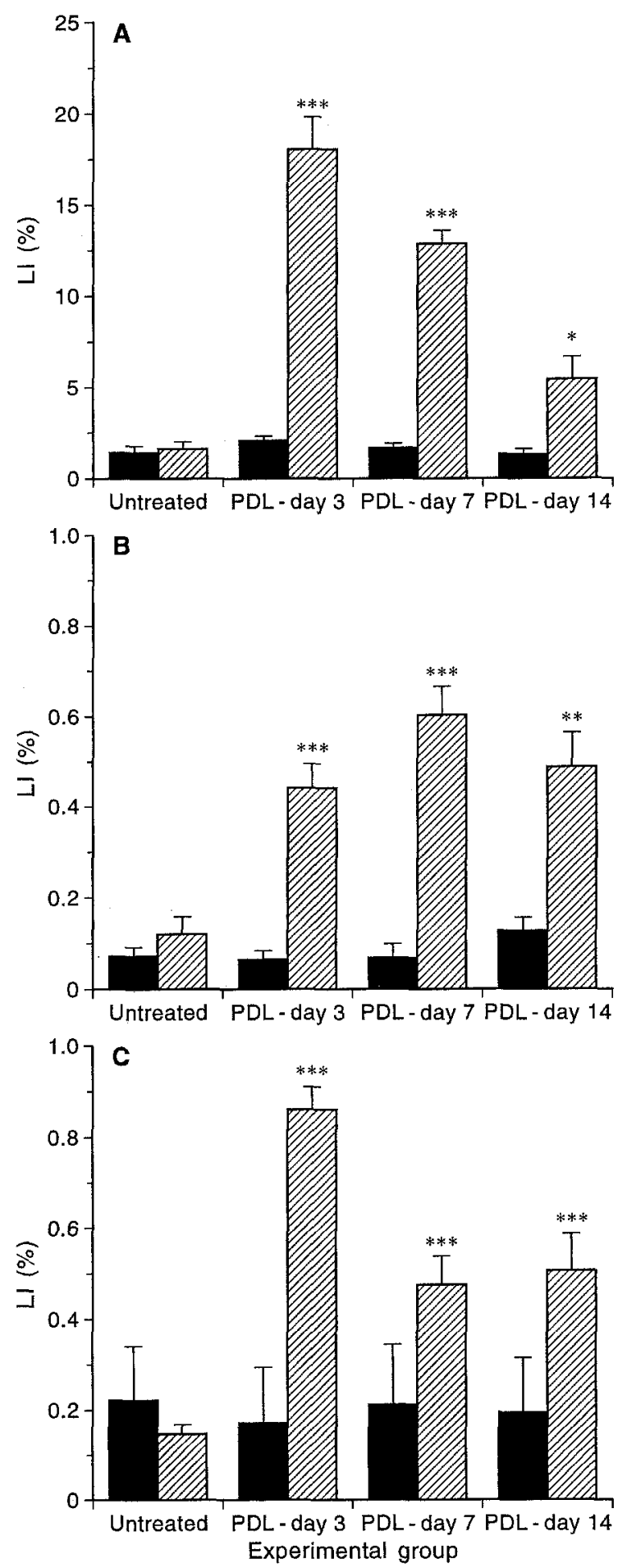

Fig. 6 (A-C). BrdU labelling indices of $\operatorname{duct}(\mathbf{A})$, beta $(\mathbf{B})$ and alpha cell $(\mathbf{C})$ in untreated and duct-ligated rats at different time points. The cells were identified by immunostaining for CK20, insulin and glucagon, respectively. * $p<0.05$; $* * p<0.01 ; * * * p<0.001$. PDL, Pancreatic duct ligation; $\square$, head portion, tail portion

could not account for their growth. A similar conclusion was reached previously for the fetal $[9,10]$ and the neonatal rat pancreas $[12,13]$. In the fetal $[6-10]$ and in the neonatal pancreas [13], the main source of new islet cells is the ductal-cell precursor compart- ment. From the present study we conclude that ductcell proliferation and differentiation is also a potent mechanism for islet neogenesis in the adult rat. Duct cells, characterized by their specific expression of CK20 [13], exhibited a dramatic proliferative activity soon after duct ligation. They showed a tenfold increase in LI, and up to one-fifth of all duct cells appeared in the S-phase of the cell cycle as demonstrated by BrdU incorporation. Double immunostaining for the ductal marker CK20 and insulin or glucagon demonstrated the presence of transitional cytodifferentiation forms between duct and beta cells or alpha cells as previously reported in the neonate [13], thereby providing direct evidence for the differentiation of duct cells into islet cells. These data also support the concept of the duct cell as a common progenitor of islet cells. To our knowledge direct evidence for such transitional cells in the adult pancreas has not been reported so far. In a recent paper, the existence of exocrine-endocrine transitional cells and of ductalexocrine transitional cells was demonstrated in interferon-gamma transgenic mice, but duct-to-islet transitional forms could not be demonstrated [17]. Unexpectedly, we found GLUT-2 which in the normal pancreas is only expressed in beta cells, also in duct cells of the ligated pancreatic tail. This indicates that the ligation-stimulated duct cells do reach a metaplastic state and acquire properties of endocrine cells. Interestingly, a recent study showed that GLUT-2 is also expressed in pancreatic ductal epithelium of the fetal rat preceding islet formation [33].

Duct ligation induced the replacement of acinar tissue by ductal tissue. It has previously been shown that after duct ligation the acinar cells rapidly die by the process of apoptosis [28, 34]. Although transdifferentiation of some surviving acinar cells might contribute to the formation of ductal complexes [35], our observation of a pronounced proliferative activity of cells expressing the ductal marker CK20 supports the notion that the duct cells are responsible for the tissue remodelling process.

It is remarkable that duct and islet-cell proliferation and differentiation occurred in the ligated part of the pancreas, while there were no histological changes in the non-ligated part of the organ. This suggests a paracrine or autocrine regulation of the observed tissue remodelling by growth factors, but little is known about the factors which regulate these events. The massive cell death attracts numerous macrophages which phagocytose dead cells $[29,34]$. Subsequently, there is an active proliferation of both stromal fibroblasts and duct cells $[31,34,36$, this study]. It has been previously suggested that the recruited macrophages may play a regulatory role in the tissue regenerative process by producing growth factors $[28,29,34,36]$. For instance transforming growth factor- $\alpha$, a factor that can be produced by macrophages, has been proposed as a regulator of 
duct-cell proliferation and differentiation [18].The identification of these factors is of interest because they could be useful to induce beta-cell regeneration in adult subjects in whom the beta-cell population has become too small to regulate glucose homeostasis, such as in diabetic patients $[19,20]$.

Acknowledgements. We are grateful to Ms. N. Buelens, Ms. A. Nuyts and Ms. E. Deblay for expert technical assistance; to Professor D. Pipeleers for helpful discussions, for insulin extraction and radioimmunoassay. This study was supported by grant No. 3009390N from the Belgian Fund for Scientific Research (NFWO).

\section{References}

1. Logothetopoulos J (1972) Islet cell regeneration and neogenesis. In: Steiner DF, Freinkel N (eds) Handbook of physiology, sect 7, Endocrinology, vol 1. American Physiological Society, Washington, pp 67-76

2. Hellerström C (1984) The life story of the pancreatic $\beta$ cell. Diabetologia 26: 393-400

3. Swenne I (1992) Pancreatic beta-cell growth and diabetes mellitus. Diabetologia 35: 193-201

4. Vinik AI (1992) Pancreatic islet cell regeneration and growth: introduction. Adv Exp Med Biol 321: 1-5

5. Swenne I (1983) Effect of aging on the regenerative capacity of the pancreatic $\beta$-cells of the rat. Diabetes 32: 14-19

6. Pictet R, Rutter WJ (1972) Development of the embryonic pancreas. In: Steiner DF, Freinkel N (eds) Handbook of physiology, sect 7. Endocrinology, vol 1. American Physiological Society, Washington, pp 25-66

7. Fuji S (1979) Development of pancreatic endocrine cell in the rat fetus. Arch Histol Jpn 42: 467 -479

8. Rutter WJ (1980) The development of the endocrine and exocrine pancreas. In: Fitzgerald PJ, Morrison AB (eds) The pancreas: Williams and Wilkins, Baltimore, pp 30-38

9. Swenne I (1982) The role of glucose in the vitro regulation of cell cycle kinetics and proliferation of fetal pancreatic $\beta$-cells. Diabetes 31: 745-760

10. Hellerström C, Swenne I (1991) Functional maturation and proliferation of fetal pancreatic $\beta$-cells. Diabetes 40 [Suppl 2]:89-93

11. Githens S (1993) Differentiation and development of the pancreas in animals. In: Go Vay Liang W, Lebenthal E, DiMagno EP, Gardner JD, Reber HA, Scheele GA (eds) The pancreas: biology, and disease. Raven Press, New York, pp $21-55$

12. Wang RN, Bouwens L, Klöppel G (1994) Beta cell proliferation in normal and streptozotocin-treated newborn rats: site, dynamics and capacity. Diabetologia 37: 1088-1096

13. Bouwens L, Wang RN, De Blay E, Pipeleers DG, Klöppel G (1994) Cytokeratins as markers of ductal cell differentiation and islet neogenesis in the neonatal rat pancreas. Diabetes 43: 1279-1283

14. Brockenbrough JS, Weir GC, Bonner-Weir S (1988) Discordance of exocrine and endocrine growth after $90 \%$ pancreatectomy in rats. Diabetes 37: 232-236

15. Bonner-Weir S, Baxter LA, Schuppin GT, Smith F (1993) A second pathway for regeneration of adult exocrine and endocrine pancreas: a possible recapitulation of embryonic development. Diabetes 42: 1715-1720

16. Sarvetnick NE, Gu D (1992) Regeneration of pancreatic endocrine cells in interferon-gamma transgenic mice. Adv Exp Med Biol 321: 85-89
17. Gu D, Sarvetnick N (1993) Epithelial cell proliferation and islet neogenesis in IFN-gamma transgenic mice. Development 118: 33-46

18. Wang TC, Bonner-Weir S, Oates PS, Chulak MB, Simon B (1993) Pancreatic gastrin stimulates islet differentiation of transforming growth factor $\alpha$-induced ductular precursor cells. J Clin Invest 92: 1349-1356

19. Rosenberg L, Vinik AI (1989) Induction of endocrine cell differentiation: a new approach to management of diabetes. J Lab Clin Med 114: 75-83

20. Rosenberg L, Vinik AI (1992) Trophic stimulation of the ductular-islet cell axis: a new approach to the treatment of diabetes. Adv Exp Med Biol 321: 95-104

21. Dudek RW, Lawrence IR, Hill R Jr, Johnson R (1991) Induction of islet cytodifferentiation by fetal mesenchyme in adult pancreatic ductal epithelium. Diabetes 40: 1041-1048

22. Hultquist GT, Jönsson LE (1965) Ligation of the pancreatic duct in rats. Acta Soc Med Upsal 70: 82-88

23. Pipeleers DG, Schuit FC, In't Veld PA et al. (1985) Interplay of nutrients and hormones in the regulation of insulin release. Endocrinology 117: 824-833

24. Weibel ER (1979) Stereological methods. In: Weibel ER (ed) Practical methods for biological morphometry, vol 1. Academic Press, London, pp 26-37

25. Oberholzer M, Heitz PU, Klöppel G, Ehrsam RE (1984) Morphometry in endocrine pathology. Path Res Pract 179: 220-224

26. Williams MA (1985) Stereological techniques. In: Williams MA (ed) Quantitative methods in biology. North-Holland, Amsterdam, pp 5-84

27. Aherne WA, Camplejohn RS, Wright NA (1977) An introduction to cell population kinetics. Edward Arnold, London, pp 88

28. Walker NI, Winterford CM, Kerr JFR (1992) Ultrastructure of the rat pancreas after experimental duct ligation. II. Duct and stromal cell proliferation, differentiation, and deletion. Pancreas 7: 420-434

29. Yamaguchi Y, Matsuno K, Goto M, Ogawa M (1993) In situ kinetics of acinar, duct, and inflammatory cells in duct ligation-induced pancreatitis in rats. Gastroenterology 104: 1498-1506

30. Edström C, Falkmer S (1967) Qualitative and quantitative morphology of rat pancreatic islet tissue five weeks after ligation of the pancreatic ducts. Acta Soc Med Upsal 72: 376-390

31. Hultquist GT, Karlsson U, Hallner A Ch (1979) The regenerative capacity of the pancreas in duct-ligated rats. Exp Pathol 17: 44-52

32. Isaksson G, Thse I, Lundquist I (1983) Influence of pancreatic duct ligation on endocrine and exocrine rat pancreas. Acta Physiol Scand 117: 281-286

33. Pang K, Mukonoweshuro C, Wong GG (1994) Beta cells arise from glucose transporter type 2 (Glut2)-expressing epithelial cells of the developing rat pancreas. Proc Natl Acad Sci 91: 9559-9563

34. Walker NI (1987) UItrastructure of the rat pancreas after experimental duct ligation. I. The role of apoptosis and intraepithelial macrophages in acinar cell deletion. Am J Pathol 126: 439-451

35. Githens S (1988) The pancreatic duct cell: proliferative capabilities, specific characteristics, metaplasia, isolation, and culture. J Pediatric Gastr Nutr 7: 486-506

36. Goto M, Matsuno K, Yamaguchi Y, Ezaki T, Ogawa M (1993) Proliferation kinetics of macrophage subpopulations in a rat experimental pancreatitis model. Arch Histol Cytol 56: 75-82 